\title{
Does dowry improve life for brides? A test of the bequest theory of dowry in rural Bangladesh
}

\author{
Luciana Suran \\ Sajeda Amin \\ Population Council \\ Lopita Huq \\ Kobita Chowdury
}

Follow this and additional works at: https://knowledgecommons.popcouncil.org/departments_sbsr-pgy

Part of the Domestic and Intimate Partner Violence Commons, Family, Life Course, and Society Commons, International Public Health Commons, and the Sociology of Culture Commons How does access to this work benefit you? Let us know!

\section{Recommended Citation}

Suran, Luciana, Sajeda Amin, Lopita Huq, and Kobita Chowdury. 2004. "Does dowry improve life for brides? A test of the bequest theory of dowry in rural Bangladesh," Policy Research Division Working Paper no. 195. New York: Population Council. 


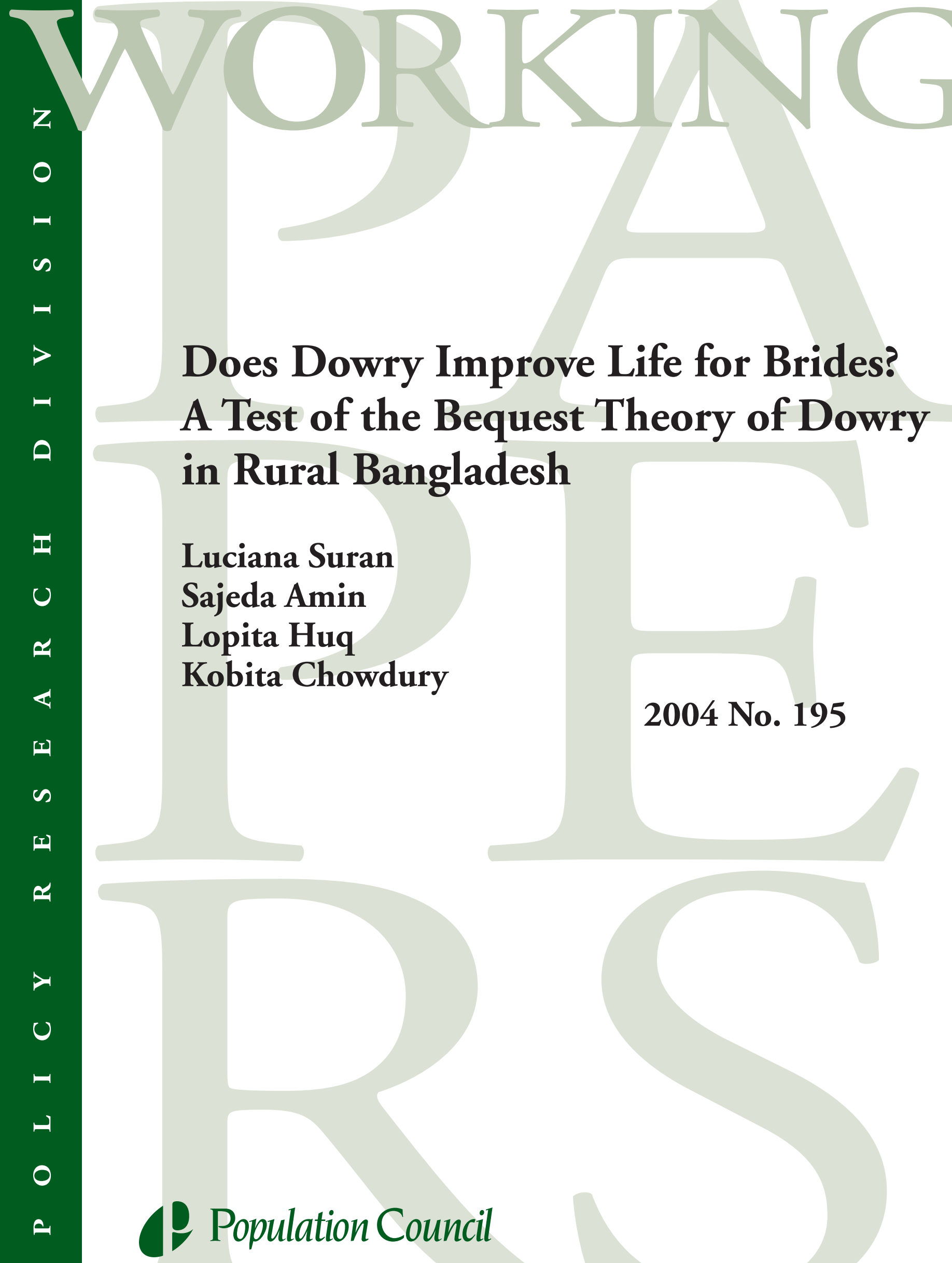




\title{
Does Dowry Improve Life for Brides? \\ A Test of the Bequest Theory of Dowry in Rural Bangladesh
}

\author{
Luciana Suran, Sajeda Amin, Lopita Huq, and Kobita Chowdury
}

Luciana Suran is Consultant and Sajeda Amin is Senior Associate, Policy Research Division, Population Council. Lopita Huq is Consultant and Kobita Chowdury is Research Coordinator, Bangladesh Institute of Development Studies, Dhaka.

Acknowledgments: This research was funded by the Andrew W. Mellon Foundation, Department for International Development, UK (DFID), UNICEF, and the United States Agency for International Development.

An earlier version of the paper was presented in the Session on "Understanding Domestic Violence in Developing Countries" at the Annual Meeting of the Population Association of America, Boston, 1-3 April 2004.

This material may not be reproduced without written permission from the authors. For a list of Policy Research Division Working Papers, including those that are currently available for downloading in PDF format, see www.popcouncil.org/publications/wp/prd/rdwplist.html.

\section{(C) 2004 The Population Council, Inc.}




\begin{abstract}
In recent years, dowry levels have risen to previously unforeseen levels. Among Hindus in north India dowry can amount to three or four times a family's total assets. Among Muslims in Bangladesh and Hindus in south India, dowry has become commonplace whereas the practice did not exist a generation ago. The institution of dowry has been widely criticized, socially maligned, and legally banned. Some recent economic writings suggest that dowry functions as a bequest or pre-mortem inheritance, implying it persists because it is "good for the bride." Using panel data from an adolescent study in rural Bangladesh, this paper explores the association between dowry and the prevalence of domestic abuse to test the bequest theory of dowry. We find that, contrary to the prediction of the bequest theory, married females who paid dowry at marriage have a higher likelihood of reporting domestic violence compared to those who did not. In addition, the relation between dowry and abuse is highly level-specific: respondents who paid small dowries report much higher levels of abuse than those who paid large dowries. In fact, paying no dowry is just as protective, if not more so, in terms of preventing abuse as the largest dowry payments.
\end{abstract}


In the growing literature on dowry, research is divided into two strands of inquiry. The first deals with marriage payments themselves (i.e., dowry or brideprice) ${ }^{1}$ and the second with the recent surge in the level of dowry payments in South Asia. The trend of rising dowries, commonly referred to as "dowry inflation," has received much attention, as payments can represent multiple years' worth of a family's income and often cause severe destitution of households with daughters of marriageable age (Deolalikar and Rao 1998). In addition, disputes over dowry payments have led to numerous cases of "dowry violence" against brides, resulting in injuries and even death.

At the same time that dowry has been widely criticized and even legally banned, recent studies suggest that dowry actually benefits the welfare of brides by acting as a form of pre-mortem inheritance. According to the bequest theory, while sons obtain their inheritance upon the death of the parents, daughters receive their share when they marry. Proponents of the bequest theory argue that by allowing daughters to gain their proper share of the family estate, dowries function as a form of parental investment and thus are not detrimental to the bride and her family. In fact, some have suggested that daughters who receive dowry stand to gain from this "investment" just as sons would benefit from a larger inheritance (Edlund 2001). Others argue that a dowry can increase the bride's bargaining power in the marital household (Zhang and Chan 1999) and even lower the probability of divorce (Esteve-Volart 2003). Such findings suggest that regardless of whether or not dowry functions purely as an inheritance, as a strict interpretation of the bequest theory would suggest, the payment of dowry should increase the bride's standing in her new household by signaling parental support of the bride.

At first glance, the bequest theory of dowry does not seem entirely implausible. In virilocal societies, that is, societies where women move to their husband's/in-laws' household upon marriage, dowries are one way in which married women can receive their proper share of the family inheritance. And even in non-virilocal societies, inheritance practices that preclude females from fully sharing in their parents' estate may justify the interpretation of dowry as a bequest. But regardless of entitlements, women who marry out are generally are not able to exercise control over their own property. For example, in most parts of Bangladesh it is common for women to give up control of their property to their brothers in exchange for rights of visitation.

In what follows we first summarize the relevant literature. Using panel data from a study in rural Bangladesh, we then present our findings concerning the effect of dowry on the incidence of domestic violence. We find that, contrary to the bequest theory, married women who paid dowry have a higher likelihood of reporting domestic violence than those who did not.

\section{THEORIES OF DOWRY}

\section{"Marriage squeeze" and female competition}

One of the most commonly cited explanations for the rise of dowry is the "marriage squeeze" argument, first introduced by Caldwell, Reddy, and Caldwell (1983). The authors noted the popular perception among villagers in south India that the appearance of dowry was due to a switch from a surplus of potential husbands to a surplus of potential brides 
beginning in the early 1970s. The key to understanding this argument is the demographic effects of declining mortality in a population in which men marry women from younger cohorts than their own. As mortality falls, younger cohorts will increase relative to older cohorts, leading to a surplus of marriageable females. Thus, the forces of supply and demand will result in a switch from brideprice to dowry. In addition, mortality reductions can affect marriage market conditions in other, less obvious ways. For example, the incidence of widowhood among men in India has declined as maternal mortality decreased, thus adding to the surplus of marriageable females (Bhat and Halli 1999). Empirical work by Rao (1993a), Bhat and Halli (1999), and Amin and Cain (1997) lent support to the idea that the marriage squeeze was a major factor in the change from brideprice to dowry in India and Bangladesh. In fact, higher ratios of males to females have been found to be positively associated with the increase in dowry payments (Rao 1993b).

In a related vein, Lindenbaum (1981) suggested that the switch from brideprice to dowry in Bangladesh was not necessarily a result of the shortage of men per se, but rather increased competition for high-quality grooms. As educational and work opportunities for men increased, parents preferred that their daughters marry educated men with urban jobs. Such men have higher and more certain incomes that are not subject to seasonal variations and are paid monthly, and the wives of such men will be free from the "drudgery" of rural work (Caldwell, Reddy, and Caldwell 1983). In other words, in the "female competition" model of marriage payments, dowry is a means by which a bride and her family can raise their status by marrying the daughter into a higher-status family, a practice known as hypergamy. Notably, it has been observed that the size of the dowry rises steeply in step with the desirable qualities of the son-in-law in a way that brideprice did not for daughters (Caldwell, Reddy, and Caldwell 1983). Thus, in the female competition model of dowry, a more correct term for dowry would be groomprice, reflecting the fact that marrying into a wealthier family can "buy" a bride and her family higher social or economic status.

At the same time, however, the qualities of the bride can significantly affect the size of the dowry. In Bangladesh, for example, dowry increases in tandem with age at marriage, placing pressure on parents to marry their daughters early. This may be especially true if the bride suffers from other disadvantages in the marriage market such as lower social status or darker skin tone (Huq and Amin 2001; Islam and Mahmud 1996).

But while the marriage squeeze can explain the switch from brideprice to dowry, it cannot explain why dowry inflation has persisted despite an equalization of cohort sizes in Bangladesh. Even though demographic projections have pointed to an easing of the marriage squeeze (Bhat and Halli 1999; Amin and Cain 1997), high dowry payments have persisted.

\section{Dowry as bequest}

The idea that dowry payments function as a pre-mortem inheritance dates back to Goody (1973, p. 17), who postulated that "dowry is part of a familial or conjugal fund, which passes down from holder to heir, and usually from the parents to the daughter." A study of Taiwanese couples that lent credence to the bequest theory of dowry found that the payment of dowry not only increases the resources of the conjugal household, but also 
increases a woman's bargaining position in her new household, leading to a rise in her welfare as measured by the probability that her husband will participate in household chores (Zhang and Chan 1999).

In addition to the argument that the very existence of dowry is beneficial to brides, some have hypothesized that dowry inflation can lead to increases in the welfare of brides. For example, Edlund (2001) suggests that rising wealth levels are responsible for the increases in dowry levels; and because daughters receive their inheritance at marriage, both dowries and inheritances will increase, thus leaving the bride better off. In this vein, rather than a social ill that is detrimental to the lives and families of young women, dowry is viewed as beneficial to the bride.

\section{DOMESTIC VIOLENCE IN BANGLADESH}

Over the past decade, the issue of domestic violence in developing countries has evolved from relative obscurity to a primary concern among researchers and policymakers who are interested in women's health and status (Koenig et al. 2003). Domestic violence has been increasingly portrayed as a public health issue given its negative impact on the physical and mental health of those who suffer such abuse. In addition, studies have shown that the harmful effects of domestic violence extend beyond the immediate victim herself. For example, victims of domestic violence are more likely to experience fetal or infant death (Jejeebhoy 1998b). Also, wives who are beaten often face a consequent loss of control over household decisions that can divert resources away from children (Rao 1998).

Some of the highest reported levels of domestic violence come from South Asia. Given the region's pronounced gender inequality and dependence of women on men, domestic violence appears to represent an accepted form of behavior in much of the subcontinent (Koenig et al. 2003; Mannan 2002). Thus, domestic violence is often justified as a "man's right" and as necessary to control the behavior of his wife (Schuler et al. 1996).

Estimated rates of domestic violence in Bangladesh range from 20 to 50 percent, depending on the reference period specified (i.e., past year or lifetime). Studies seeking to estimate the proportion of wives in Bangladesh who have ever experienced abuse report that around 40 to 50 percent of women have been physically assaulted by their husbands (Bhuiya, Sharmin, and Hanifi 2003; Koenig et al. 2003; Mannan 2002; Schuler et al. 1996; UNFPA 2000). On the other hand, when asked about abuse in the past year, about 20 percent of women in Bangladesh report domestic violence (Schuler et al. 1996).

Recent studies suggest a link between domestic violence and dowry demands. Wife abuse has been found to be higher when a husband and/or his family believes dowry payments are inadequate (Banerjee 1999; Bloch and Rao 2002). These instances of "dowry violence" stand in stark contrast to the bequest theory of dowry. If dowry does indeed function as an investment given by altruistic parents in the form of a pre-mortem inheritance, one would expect brides who pay dowry to face a lower likelihood of experiencing domestic violence. Moreover, the welfare of brides who pay dowry should increase as dowry levels rise. 


\section{DATA AND MeThod \\ Quantitative data}

This study uses panel data obtained in 2003 from three districts (Chapainawabganj, Chittagong, and Sherpur) in rural Bangladesh as part of a three-year intervention program

on adolescent livelihoods. ${ }^{2}$ The survey used a stratified random sample approach. Each village included in the survey was selected randomly from lists provided by the two implementing organizations, BRAC (Bangladesh Rural Advancement Committee) and CMES (Centre for Mass Education in Science), at least one of which was planning to work there. Control villages were selected from among those in which no intervention was planned and were chosen from the same general area on the assumption that they would be similar in most respects to the intervention villages. All households in each village were listed and numbered and every third household was visited. One adolescent was interviewed from each household. In households with more than one adolescent, one was selected using a Kish grid. Sampling weights were used in all analyses to account for a small proportion of respondents from intervention areas who were selected purposively to ensure adequate representation of girls who were expected to join an intervention program. ${ }^{3}$ The final completed survey consisted of 2,211 female adolescents aged 15 to 24 years. The sample used in this analysis was restricted to currently married adolescent girls $(\mathrm{N}=1,279)$.

\section{Qualitative data}

Qualitative data were collected from program implementers and beneficiaries during the course of the intervention. In total, 31 respondents were followed and interviewed approximately every four months between January 2001 and July 2004. Field workers used open-ended questionnaires to obtain detailed descriptions of the respondents' background experiences and to elicit respondents' beliefs and opinions concerning a number of issues, including marriage, education, and local and global events. Family members were also interviewed, as well as marital family members for those respondents who were married. All discussions were tape recorded and then transcribed.

\section{Measurement}

The dependent variable is a dummy indicating whether or not a respondent experienced a physical beating in the previous 12 months. We also have information on who performed the beating. Because the sample was limited to currently married females, the large majority (95 percent) reported that their husband performed the beating. (Other abusers included mothers and unnamed relatives.) All dowry amounts were corrected for inflation using the price of rice in the respondent's district for her year of marriage. Since rice is the major crop in rural Bangladesh, its price has been found to be an appropriate price deflator (Khan and Hossain 1989). In addition, unlike many studies on dowry that calculate dowry payments by netting brides' family assets and husbands' family assets, our data contain information both on the amount of dowry paid at marriage and on additional dowry payments made after the marriage. These "post-marriage" dowry payments have not previously been empirically examined in the literature on dowry. 


\section{RESULTS}

Table 1 provides background characteristics of the 1,279 married female respondents between ages 15 and 24. Approximately 20 percent of respondents reported experiencing a beating in the past year. Three-quarters of the respondents paid a dowry at marriage, with a mean payment of 10,187 Bangladeshi taka. ${ }^{4}$ The large standard deviation reflects the wide variation in dowry payments, which ranged from 500 to 160,000 taka. ${ }^{5}$ In addition, 9 percent made a dowry payment after marriage, with a mean payment of 561 taka. Three-quarters of respondents reported enrollment in school at some period during their lives, with a mean amount of schooling of about 5 years. Approximately half of the respondents are married to husbands with less than primary education. ${ }^{6}$ Some 40 percent of respondents reported ever working for pay. ${ }^{7}$ In addition, approximately 20 percent reported having taken a loan, the majority (90 percent) from NGOs conducting microcredit activities in the study area.

\section{The practice of dowry payments}

While the practice of dowry is widespread, it is an emergent rather than a longstanding practice among Muslims in Bangladesh. In addition, the fact that dowry has been illegal in Bangladesh since the Dowry Prohibition Act of 1980 contributes further to keeping the practice fluid and vague.

Despite the absence of hard evidence on the practice of dowry, our qualitative data as well as observations in the field allow us to make several generalizations. The family of the bride will often disclose to their friends, neighbors, and marriage brokers the amount of dowry they are willing to pay for a suitable groom, particularly if the proposed amount is relatively high. Both parties to the marriage contract often haggle about the price, and a marriage broker will mediate between them, often going back and forth several times with offers and counter-offers. It is not uncommon for a negotiation to "fall through" if an agreement regarding the dowry cannot be reached. A portion of the dowry may be given before the marriage ceremony takes place to help defray expenses the groom will incur at the marriage. The remaining transaction usually occurs at the marriage ceremony. Among poorer families and for marriages taking place during non-harvest periods, the parties may agree in advance that a portion of the dowry will be paid later (e.g., after the harvest). In any case, our field observations suggest that the payment of dowry is never made in public, most likely because of its illegality.

A number of factors determine the size of the dowry and whether it is even paid. While various characteristics of brides and grooms (e.g., age and wealth) are known to affect the size of the dowry, circumstances can affect the importance placed on any one factor. For example, while wealthier families and families of older brides tend to pay greater amounts, dowry is likely to be less important if a bride marries into a family of equal status (Jansen 1986). The bride's physical characteristics can also play a role. Lightskinned girls, who are in high demand, get married relatively early and with very little dowry.

But while physical appearance can be an asset in the marriage market, it can also have perverse affects. The parents of an attractive girl can end up having to pay a large 
dowry if her beauty leads to envy, gossip, and a tarnished reputation. Thus, the effect that a girl's good looks has on dowry is mediated by both the groom's opinion of his potential bride and the social context in which the marriage negotiations are held. Moreover, exogenous factors impinging on the household of a potential bride, such as a financial crisis, can also affect negotiations.

\section{Quantitative analysis}

To evaluate the effect of dowry payments on the likelihood that a married female reported experiencing physical abuse, we ran a series of nested logistic regression models in order to adjust for demographic covariates. The Wald test ${ }^{8}$ was used to determine whether each new set of variables significantly improved model fit. The first set includes geographic indicators in the form of district dummy variables and a dummy variable for the type of village (i.e., intervention or control). The second model includes variables such as education, natal family wealth, and age at marriage to control for characteristics of the bride. Likewise, the next model adds variables to control for groom characteristics. The fourth model adds the main variables of interest. A dummy variable is added to indicate whether the respondent paid dowry at marriage. In addition, a second dummy variable was added to indicate whether a "post-marriage" dowry payment took place. The final model adds post-marriage household variables such as contraceptive use and presence of children in the household to obtain a more complete set of determinants of domestic violence.

Results of the multivariate logistic regression models ${ }^{9}$ predicting the likelihood that respondents reported being abused in the past year are presented in Table 2.

\section{a) Geographic area}

In Model 5, compared to respondents from the district of Chapainawabganj, respondents from Chittagong and Sherpur were more likely to report having experienced abuse in the past year, with odds ratios of 3.1 and 1.8, respectively. The lower odds of experiencing domestic violence in Chapainawabganj may be related to the less conservative nature of this district. Several studies show that Chapainawabganj and other districts located on the border of West Bengal are more receptive to changing roles for women (Amin, Basu, and Stephenson 2002). Furthermore, the significance of the district variables even after controlling for other factors such as wealth and age suggests that communitylevel effects play important roles in the prevalence of domestic violence in rural Bangladesh (as discussed by Koenig et al. 2003).

Compared to respondents from control villages, the odds of reporting domestic violence are 1.5 times larger for respondents in intervention villages, which may be related

to the intervention programs' focus on gender relations. However, in Model 5 this variable is not statistically significant at the 0.10 level.

\section{b) Respondents' characteristics}

Variables concerning respondent (bride) characteristics, added in Model 2, significantly improve model fit at the 0.01 level. As expected, higher levels of respondents' education, measured in terms of years of schooling, decrease the likelihood that a 
respondent reported being abused. In Model 5, the odds of having been beaten in the past year are reduced by a factor of about 1.0 for every unit increase in years of schooling. However, the effect of schooling is not statistically significant in this final model, suggesting that, after controlling for other factors, the odds of experiencing domestic violence are not affected by levels of education.

Compared to those respondents in the poorest quartile, wealthier respondents are less likely to report violence, and this effect is more prominent the wealthier the respondent. This finding suggests that the economic background of a bride's family matters significantly with regard to her treatment in the marital home. In addition, the insignificant schooling effect compared with the significant wealth effect suggests that education influences the likelihood of violence through its role as a proxy for wealth. In other words, the decreased incidence of domestic violence associated with higher education may be due to the higher wealth levels of those with more education, rather than to higher education itself. On the other hand, one could argue that the lower likelihood of violence among the wealthy or the better educated might be due to differences in reporting-wealthier and better-educated respondents might be more inclined to deny experiencing abuse if they associate domestic violence with members of poorer classes.

Dummy variables concerning whether or not the respondent's mother and father were alive at the time of the survey were included. One might expect a woman to experience a decreased likelihood of domestic violence if her parents, especially the father, are alive. We found that respondents whose fathers are alive are less likely to report abuse $(\mathrm{OR}=0.8)$ compared to those whose fathers were deceased at the time of the survey. On the other hand, with an odds ratio of 1.0, respondents with living mothers are neither more nor less likely to report abuse. However, neither of the findings is statistically significant at the 0.10 level.

Respondents were also asked whether they had ever worked for pay, which refers to either intra-household labor (e.g., animal husbandry) or extra-household labor (e.g., work in a garment factory). As shown in Table 2, the odds of reporting domestic violence are 1.4 times larger for respondents with paid labor experience than for those without such experience, and the difference is statistically significant at the 0.05 level.

The final two indicators included in Model 2 are age at marriage and whether the respondent is divorced. Age at marriage does not affect the likelihood of domestic violence. While this finding might seem surprising, it is most likely attributable to the inclusion of natal family wealth in the model. Given that dowries and age at marriage are positively related, wealthier families are, ceteris paribus, better able to delay marriage. Lastly, the likelihood of experiencing domestic violence is not significantly different for divorced respondents $(\mathrm{OR}=1.6)$.

\section{c) Husbands' characteristics}

Variables concerning groom characteristics, such as wealth and educational background, were added to Model 3 to control for effects they might have on the likelihood that a woman reported experiencing domestic violence. The addition of these variables significantly improves model fit at the 0.01 level. Compared to respondents whose 
husbands have less than a primary education, the likelihood of reporting abuse decreases significantly only when husbands have attained secondary educational levels $(\mathrm{OR}=0.5)$, suggesting diminishing returns to male education in decreasing the likelihood of domestic violence.

Intriguingly, the data do not show a statistically significant relationship between the wealth of the groom's family and the likelihood that a respondent reported domestic violence. This finding suggests that characteristics of the bride are more important than those of the groom in predicting wife abuse.

\section{d) Dowry variables}

Two variables related to dowry payments were included in Model 4. The addition of these two variables significantly improves model fit at the 0.01 level. The first is a dummy variable that equals 1 if the respondent paid dowry at marriage and 0 otherwise. The second dummy variable equals 1 if the respondent paid dowry after marriage and 0 otherwise. $^{10}$ If the bequest theory is valid, that is, respondents who pay dowry are more likely to be treated well by the groom and his family, one would expect the odds ratios for these variables to be less than one. The data, however, show the opposite to be the case. Respondents who paid dowry are more likely to have been beaten in the past year (OR= 1.6), a finding that is statistically significant at the 0.05 level. Moreover, respondents who made post-marriage dowry payments ${ }^{11}$ exhibit much higher odds of reporting domestic violence $(\mathrm{OR}=2.0)$, and this result is statistically significant at the 0.01 level.

At first glance, such post-marriage payments may not seem to be a salient factor in the well-being of brides, but recent research has emphasized that payments demanded after negotiations for marriage and dowry have been settled are of growing importance in the marriage market (Bloch and Rao 2002). Although dowry amounts are traditionally negotiated before the marriage ceremony, oftentimes a husband, in concert with his family, will later demand that the bride's family pay a larger dowry, in the form of cash or goods such as a motorbike, and will threaten to harm the bride if the demands are not met. ${ }^{12}$ Our findings concur with recent studies suggesting that dowry has evolved into a form of "institutionalized extortion" in which violence or threats of violence are used to extort money or property from the bride's relatives, sometimes in excess of what was promised at the time the marriage was negotiated (Schuler et al. 1996, p. 1733). We agree with Bloch and Rao (2002), who point out that "dowry violence" refers not only to disputes directly related to payments made at the time of the wedding, but also to additional payments that are demanded after the marriage has taken place. Among those respondents in our sample who did not pay dowry at marriage, only about 9 percent reported making a post-marriage dowry payment-but this figure climbs to 27 percent among those who paid dowry at marriage.

\section{e) Post-marriage household characteristics}

Variables related to the wife's welfare after marriage were also included for completeness, and the addition of these variables significantly improves model fit at the 0.01 level. The number of years spent in marriage was included as a continuous variable to 
determine any relationship between time spent in the marital household and the likelihood that a respondent experienced domestic violence in the past year. With an odds ratio of 1.05 , the likelihood that a respondent reports abuse increases by a factor of 0.05 for each additional year of marriage, although this is not statistically significant at the 0.10 level. Of course, our results pertain only to young women (maximum age of 24 years) and thus are likely to differ from results for women in a broader age range. In addition, little agreement exists as to the effect of years of marriage on the incidence of domestic violence. Several studies have reported a decreasing risk of violence with the increasing age of the wife (Schuler et al. 1996), whereas others have found no association (Jejeebhoy and Cook 1997).

Variables concerning current contraceptive use and the presence of children in the household were also added, as well as an interaction between the two variables. Women who were using contraception at the time of the survey were less likely to report domestic violence by a factor of 0.8 , although this finding is not statistically significant. Respondents with living children are more likely to report abuse (OR=1.4).

Variables related to the incidence of loan use and STI infection were also included since studies have shown these factors to play important roles in the well-being of married females. The issue of loan use is of particular importance as microcredit organizations have undergone increased expansion in rural Bangladesh and organizations such as the Grameen Bank have made a concerted effort to provide loans to women. Respondents who reported having suffered from a sexually transmitted infection were more likely to report abuse $(\mathrm{OR}=1.6)$, a finding that is statistically significant at the 0.05 level. This finding concurs with a recent study linking men's sexual fears and inadequacies to increased violence against women (Verma and Collumbien 2003). Loan use has a strong positive association with the likelihood of reporting domestic violence $(\mathrm{OR}=1.8)$ and is significant at the 0.01 level. However, this result should be interpreted with caution, as previous studies suggest a high degree of self-selection in microcredit participation (Steele, Amin, and Naved 2001). Numerous studies have attempted to ascertain the effect of microcredit participation on wife abuse, yet no agreement exists on the relationship between them. While some have found that loan use leads to a decreased incidence of wife beating (Schuler et al. 1996), others have found that participation in microcredit activities increases domestic violence (Rahman 1999).

In sum, we find that respondents who paid dowry exhibit a higher likelihood of experiencing domestic violence. These findings are arresting given that our qualitative data suggest that parents often give dowry in the hope that their daughter will be treated better in her marital home.

\section{Violence and the size of dowry}

Thus far we have analyzed those who paid dowry compared to those who did not. But given that dowry payments vary considerably, combining all sizes of dowry payments might hide differences in outcomes experienced by brides according to the amount paid. In other words, if the payment or nonpayment of dowry affects the likelihood of experiencing domestic violence, then the size of dowry plays an important role as well. 
The size of dowry is related to and determined by the wealth of a bride's family. In other words, the size of the dowry relative to the wealth of a bride's family may play an important role in how the size of a dowry is perceived, as dowries tend to rise in tandem with wealth. In order to separate the effects of household wealth on the amount of dowry paid, we first calculated quartiles of dowry payments for each wealth quartile separately. In each wealth quartile, those respondents who did not pay dowry were treated as a separate category. This left us with 20 categories. We reran the logistic regression model using these categories as binary variables instead of the two dowry-related variables used earlier in the paper (results not shown). We then calculated the predicted probabilities of reporting domestic abuse during the previous year. These data are displayed graphically in Figure 1.

Several interesting findings emerge from this graph. Most notably, it appears that a critical factor in clarifying the relationship between dowry and domestic violence is whether or not a dowry was paid at all. In each household wealth ranking, those who did not pay dowry exhibit a relatively low risk of experiencing violence. However, among respondents who did pay dowry, the likelihood of experiencing domestic abuse appears to be inversely related to the level of dowry paid. Those who paid small dowries face a high risk of violence, both overall and within each household wealth quartile. On the other hand, respondents who paid very large dowries generally face a decreased risk of violence among those who paid dowry.

At the same time, those who paid no dowry face the lowest risk of abuse. In other words, the bequest theory's proposition that dowries leave brides better off appears to be valid for those who paid very high dowries, but only among those who chose to pay dowry in the first place. Once a family decides to pay dowry for a daughter's wedding, only a very large payment appears to be associated with a lower risk of domestic violence. If the bequest theory is a valid description of the dowry system, one would expect a linear relationship between the amount of dowry paid and the well-being of brides. But this is true only among those who chose to pay dowry. Thus, the inclusion in the analysis of those who did not pay dowry introduces an element of non-linearity in the proposition that higher dowries increase the well-being of brides.

One potential objection to our analysis is related to the issue of causality. For example, the type of husband whom one can marry with a small dowry could be the kind of spouse more likely to beat his wife because his prospects for success are slight. But if dowry does indeed function as the price paid for a groom, as this line of reasoning suggests, then one would expect those who did not pay dowry to be the group with the highest risk of violence. However, we do not find this to be the case. Those who did not pay dowry at all are one of the groups with the lowest risk of violence.

\section{DiscuSSION AND CONCLUSION}

Our analyses suggest that a key component of the association between dowry and the well-being of wives appears to depend not only on the amount of dowry given, but on whether dowry was paid at all. Among those respondents who paid dowry, only those who paid the largest amounts enjoy a decreased risk of violence. This finding does not appear to be related solely to respondents' wealth status: in each household wealth quartile, among 
those who paid dowry, only those who paid the largest dowries face a reduced likelihood of abuse. Those who paid no dowry at all face a similarly low risk, and a lower risk overall. The decision to pay dowry therefore represents a critical choice. Once a family decides to pay dowry, the best way to secure their daughter's welfare is to pay the most that they can.

Perhaps the most obvious objection to the bequest theory of dowry is the observation that the growing practice of dowry has been "widely deplored and no one suggests that its practice is spiritually or socially uplifting" (Caldwell, Reddy, and Caldwell 1983). But a more meaningful criticism of the bequest theory is its ignorance of the social processes of dowry payments as well as changes in dowry payments that have occurred over the past 30 years. For example, the assumption of the bequest theory that the bride retains control over the dowry is questionable. Dowry is not transferred to the bride, nor does a daughter gain control over the dowry in the way in which a son gains control over land following the partition of his father's estate. In fact, even the groom's control over the dowry is likely to be subordinate to that of his parents as long as the latter are alive (Sharma 1980). This observation agrees with findings that having in-laws who are dissatisfied with the dowry amount increases nearly fourfold the likelihood of being beaten (Verma and Collumbien 2003). In those instances in which women do exercise some control over their dowries, however, they are significantly less likely to suffer beating and intimidation (Bloch and Rao 2002; Jejeebhoy 1998a), suggesting that brides' control over dowry is an important factor determining their treatment in the marital home.

Changes in the nature of dowry payments themselves have made it more difficult for brides to retain control over dowry. While dowry was previously characterized by physical objects in the form of household goods, today cash is a larger component of the marriage payment (Amin and Cain 1997). Some (e.g., Sandanshiv and Mathew 1995) have suggested that the conversion to cash is at least partly to blame for the transformation of dowry into a means of extorting money and expensive goods from the bride's family. A compounding factor is the fact that dowry is often not a one-time payment, but is openended in nature (Tambiah 1973, p. 92), making the bride and her family more susceptible to additional demands. Furthermore, given that dowry inflation is a relatively recent phenomenon, the positive justification of dowry as a form of pre-mortem inheritance may turn out to be a misguided assumption.

Future research on marriage payments would benefit from an examination of what factors make families more likely to avoid paying dowry. Our data suggest that the nonpayment of dowry is related both to higher income levels and to geographic location, as the non-payers in our sample were relatively more wealthy and lived in less traditional areas of our sample. Further work to discover what induces families to avoid paying dowry can help programs reach families susceptible to dowry demand and its negative consequences. 
Table 1 Demographic and personal characteristics of the study population of 1,279 married females aged 15 to 24

\begin{tabular}{|c|c|c|}
\hline & Mean & $\begin{array}{l}\text { Std. } \\
\text { Dev. }\end{array}$ \\
\hline$\%$ experienced beating in past year & 20.3 & 1.1 \\
\hline$\%$ paid dowry at marriage & 76.2 & 1.2 \\
\hline Amount of dowry paid at marriage (Tk. $)^{\mathrm{a}}$ & 10,187 & 15,926 \\
\hline$\%$ paid dowry after marriage & 9.2 & 0.8 \\
\hline Amount of dowry paid after marriage (Tk. $)^{a}$ & 561 & 3,000 \\
\hline Age at marriage (years) & 15.3 & 2.2 \\
\hline Current age (years) & 20.1 & 2.8 \\
\hline$\%$ ever enrolled in school & 76.8 & 1.2 \\
\hline Mean years schooling & 4.9 & 3.8 \\
\hline \multicolumn{3}{|l|}{ Husband's schooling } \\
\hline$<5$ years & 52.8 & \\
\hline 5 years & 16.3 & \\
\hline $6-10$ years & 16.7 & \\
\hline $10+$ years & 14.2 & \\
\hline$\%$ with children & 72.2 & 1.3 \\
\hline Number of children & 1.1 & 0.9 \\
\hline Current contraceptive use & 59.6 & 1.4 \\
\hline STI incidence & 18.1 & 1.1 \\
\hline$\%$ ever worked for pay & 41.6 & 1.4 \\
\hline Loan use history (\%) & 23.4 & 1.2 \\
\hline$\%$ divorced & 3.6 & 0.5 \\
\hline
\end{tabular}

${ }^{a}$ Tk. 59= US\$1 in 2001. 
Table 2 Multivariate logistic regression models of covariates of having been beaten in the past year

\begin{tabular}{|c|c|c|c|c|c|c|}
\hline Variable & Variable description & Model 1 & Model 2 & Model 3 & Model 4 & Model 5 \\
\hline Geographical indicators & \multirow{4}{*}{ categorical } & OR & OR & OR & OR & OR \\
\hline $\begin{array}{l}\text { District } \\
\text { Chapainawabganj (base) }\end{array}$ & & 1.0 & 1.0 & 1.0 & 1.0 & 1.0 \\
\hline Chittagong & & $2.1^{*}$ & $3.1^{*}$ & $3.3^{*}$ & $3.2 *$ & $3.1^{*}$ \\
\hline Sherpur & & $1.8^{*}$ & $1.7 * *$ & $1.7^{* *}$ & $1.6^{* *}$ & $1.8^{*}$ \\
\hline Village type & $\begin{array}{r}\text { binary ( } 0 \text { if control, } \\
1 \text { if intervention) }\end{array}$ & 1.2 & $1.6^{* * *}$ & $1.6^{* * *}$ & $1.5^{* * *}$ & 1.5 \\
\hline Respondent's background & \multirow{6}{*}{$\begin{array}{l}\text { continuous } \\
\text { categorical }\end{array}$} & & & & & \\
\hline $\begin{array}{l}\text { Years of schooling } \\
\text { Household wealth }\end{array}$ & & & $0.9^{*}$ & $0.9^{* *}$ & $0.9^{* *}$ & 1.0 \\
\hline Poorest quartile & & & 1.0 & 1.0 & 1.0 & 1.0 \\
\hline $2^{\text {nd }}$ poorest quartile & & & $0.5^{*}$ & $0.5^{*}$ & $0.4^{*}$ & $0.4 *$ \\
\hline $3^{\text {rd }}$ poorest quartile & & & $0.4^{*}$ & $0.4^{*}$ & $0.4^{*}$ & $0.4^{*}$ \\
\hline Wealthiest quartile & & & $0.2^{*}$ & $0.2 *$ & $0.2 *$ & $0.2 *$ \\
\hline Father alive? & binary & & 0.9 & 0.8 & 0.8 & 0.8 \\
\hline Mother alive? & binary & & 1.0 & 1.0 & 1.0 & 1.0 \\
\hline Work for pay? & binary & & $1.6^{*}$ & $1.6^{*}$ & $1.6^{*}$ & $1.4 * *$ \\
\hline Age at marriage & continuous & & 1.0 & 1.0 & 1.0 & 1.0 \\
\hline Divorced? & binary & & 1.3 & 1.2 & 1.3 & 1.6 \\
\hline Husband's background & & & & & & \\
\hline$<5$ years & \multirow{9}{*}{ categorical } & & & 1.0 & 1.0 & 1.0 \\
\hline 5 years & & & & 1.2 & 1.1 & 1.3 \\
\hline $6-10$ years & & & & $0.5^{* *}$ & $0.5^{* *}$ & $0.5^{* *}$ \\
\hline $10+$ years & & & & 0.8 & 0.9 & 0.8 \\
\hline Household wealth & & & & & & \\
\hline Poorest quartile & & & & 1.0 & 1.0 & 1.0 \\
\hline $2^{\text {nd }}$ poorest quartile & & & & 1.1 & 1.1 & 1.0 \\
\hline $3^{\text {rd }}$ poorest quartile & & & & 1.3 & 1.4 & 1.3 \\
\hline Wealthiest quartile & & & & 1.3 & 1.4 & 1.0 \\
\hline Dowry & & & & & & \\
\hline Paid dowry & binary & & & & $1.5^{* * *}$ & $1.6^{* *}$ \\
\hline Paid post-marriage dowry & binary & & & & $1.8^{*}$ & $2.0^{*}$ \\
\hline \multicolumn{2}{|c|}{ Post-marriage household variables } & & & & & \\
\hline Years of marriage & continuous & & & & & 1.1 \\
\hline Current contraceptive use & binary & & & & & 0.8 \\
\hline Has children & binary & & & & & 1.4 \\
\hline Contraceptive use $*$ children & binary & & & & & 2.1 \\
\hline STI & binary & & & & & $1.6^{* *}$ \\
\hline Loan use & binary & & & & & $1.8^{*}$ \\
\hline \multicolumn{3}{|c|}{ Diff. in model $\chi^{2}$ for additional covariates } & $143.4^{*}$ & $11.0 * * *$ & $11.8^{*}$ & $50.1 *$ \\
\hline
\end{tabular}


Figure 1 Predicted probability of being beaten among currently married women by quartiles of household wealth and of dowry

$$
\text { payments }(2003)(\mathrm{N}=1,279)
$$

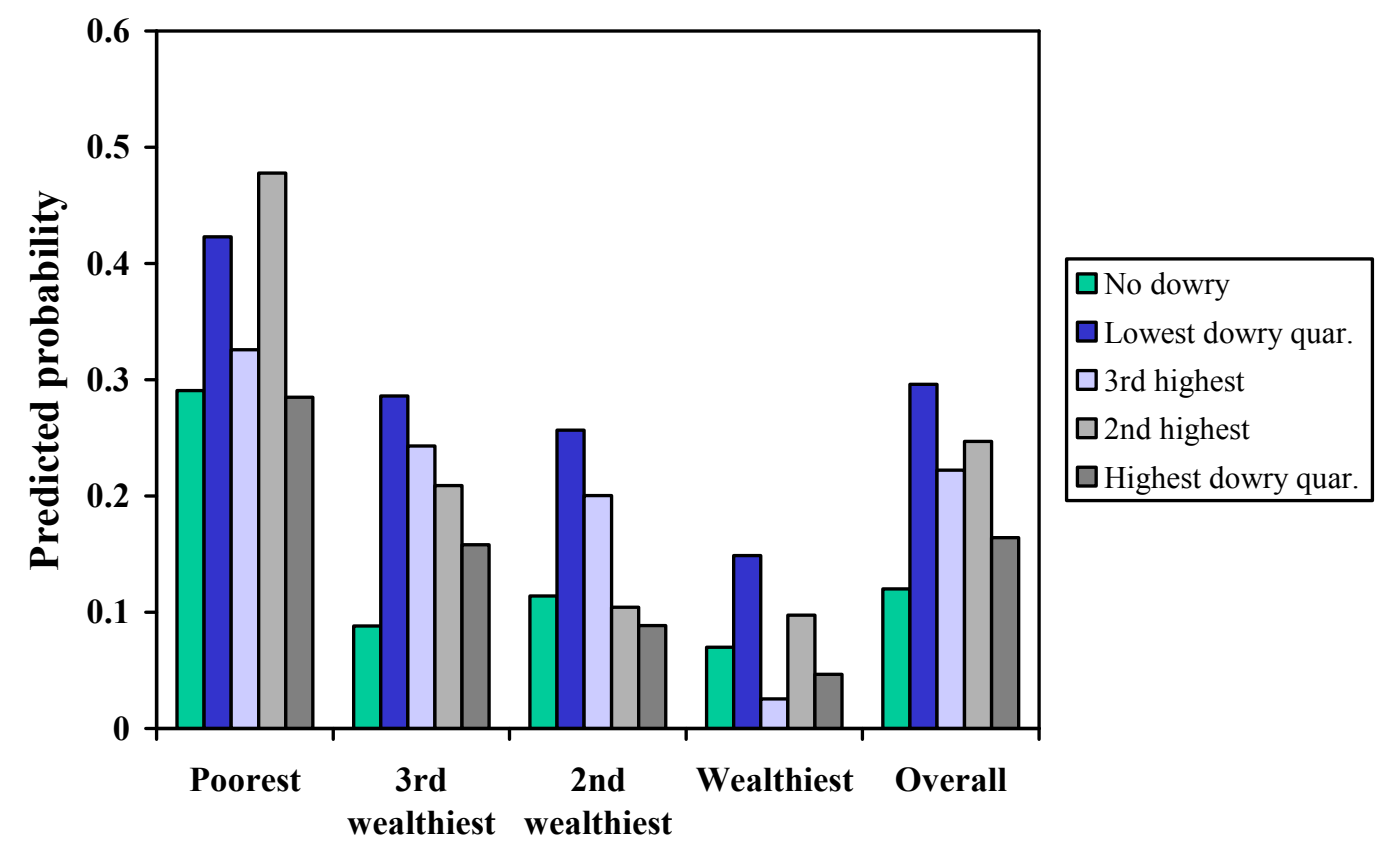

Household wealth quartiles 


\section{NOTES}

1 Dowry (also known in the literature as groomprice) refers to payments made to the groom and his family by the bride's family, while brideprice refers to payments made in the opposite direction.

2 An initial 2001 survey targeted 6,000 girls and boys between the ages of 13 and 22. As a result of budgetary constraints, the 2003 survey was limited to females, and the number of villages included was lowered from 90 to 69 . In addition, of the respondents who had migrated out of their villages, only those who remained in the same district were included in the sample. Thus, of the 2,386 respondents with whom second interviews had been attempted, 2,211 were successfully interviewed. This low attrition rate of 93 percent is of critical importance in a study of marriage payments, given that marriage is the single most important reason for migration among females of this age group in the study areas.

3 Any adolescent girl or young woman who had previously attended a BRAC or CMES school and had not been sampled randomly was included in the purposive sample.

4 Tk. 59=US\$1 in 2001.

5 Unadjusted figures.

6 Data concerning husbands' education was available only in categorical form.

7 The percentage of respondents who reported ever having worked for pay increased substantially between the baseline and midline rounds of data collection. We believe this is due in part to changing awareness of women's contribution to household income and in part due to a substantial rise in backyard poultry farming to earn cash that is a common activity among young women in the study area. Thus, women who may have received compensation for household activities such as selling eggs may have been more likely to equate such work with paid labor.

8 Given the use of sampling weights and the controlling of clustering at the village level, the Wald test rather than the likelihood ratio test was used (see Greene 1997 for further explanation).

9 Standard errors have been corrected for heteroskedasticity.

10 The purpose of entering these variables in a binary format was to ascertain the overall effect of dowry payment on the incidence of domestic violence. Later in the paper we address the association between different levels of dowry and domestic violence.

11 Although this variable was designed to elicit information concerning the payment of the dowry agreed upon before marriage after the marriage had taken place, field staff reported that respondents interpreted the survey question to indicate any additional payments made after marriage. Regardless of the interpretation, we suggest that the timing of the dowry payment may represent an important factor in the relationship between dowry and the welfare of wives.

12 In fact, of the 118 respondents who paid dowry after marriage, over half reported experiencing domestic violence in the past year. In addition, of those respondents who paid dowry after marriage, only 11 ( 9 percent) had not made a dowry payment at marriage - in other words, those respondents who paid dowry at marriage were much 
more likely to make an additional dowry payment than were those who had not paid a dowry earlier.

\section{REFERENCES}

Amin, Sajeda, Alaka M. Basu, and Rob Stephenson. 2002. "Spatial variation in contraceptive use in Bangladesh: Looking beyond the borders," Demography, 39(2): 251-267.

Amin, Sajeda and Mead Cain. 1997. "The rise of dowry in Bangladesh," in The Continuing Demographic Transition, eds. G. W. Jones et al. Oxford, England: Clarendon Press, pp. 290-306.

Anderson, Siwan. 2003. "Why dowry payments declined with modernization in Europe but are rising in India," Journal of Political Economy, 111(2): 269-310.

Banerjee, Kakoli. 1999. "Gender stratification and the marriage market in India," Journal of Family Issues, 20(5): 648-676.

Bhat, P. N. Mari and Shiva S. Halli. 1999. "Demography of brideprice and dowry: Causes and consequences of the Indian marriage squeeze," Population Studies, 53(2): 129-148.

Bhuiya, A.U., T. Sharmin, and S. M. Hanifi. 2003. "Nature of domestic violence against women in a rural area of Bangladesh: Implication for preventive interventions," Journal of Health, Population and Nutrition, 21(1): 48-54.

Billig, M. S. 1992. "The marriage squeeze and the rise of the groom-price in India's Kerala state," Journal of Comparative Studies, 23: 197-216.

Bloch, Francis and Vijayendra Rao. 2002. "Terror as a bargaining instrument: A case study of dowry violence in rural India," The American Economic Review, 92(4): 10291043.

Caldwell, J.C., P. Reddy, and P. Caldwell. 1983. "The causes of marriage change in South India," Population Studies, 37: 343-361.

Deolalikar, Anil B. and Vijayendra Rao. 1998. "The demand for dowries and bride characteristics in marriage: Empirical estimates for rural south-central India," in Gender, Population and Development, eds. M. Krishnaraj et al. Delhi: Oxford University Press. 
Edlund, Lena. 2001. "Dear son-expensive daughter: Do scarce women pay to marry?," mimeo. New York: Columbia University.

Esteve-Volart, Berta. 2003. "Dowry in rural Bangladesh: Participation as insurance against divorce," mimeo. London: London School of Economics.

Goody, Jack 1973. "Bridewealth and dowry in Africa and Eurasia," in Bridewealth and Dowry, eds. Jack Goody and Stanley J. Tambiah. Cambridge: Cambridge University Press.

Greene, William H. 1997. Econometric Analysis. Upper Saddle River, NJ: Prentice Hall.

Huq, Lopita and Sajeda Amin. 2001. "Dowry negotiations and the process of union formation in Bangladesh: Implications of rising education," unpublished manuscript.

Islam, M. Mazharul and Mamun Mahmud. 1996. "Marriage patterns and some issues related to adolescent marriage in Bangladesh," Asia-Pacific Population Journal, 11(3): 27-42.

Jansen, Eirik G. 1986. Rural Bangladesh: Competition for Scarce Resources. Oslo: Norwegian University Press.

Jejeebhoy, Shireen J. 1998a. "Wife-beating in rural India: A husband's right? Evidence from survey data," Economic \& Political Weekly, 33: 855-862.

. 1998b. "Associations between wife-beating and fetal and infant death: Impressions from a survey in rural India," Studies in Family Planning, 29(3): 300-308.

Jejeebhoy, Shireen J. and Rebecca J. Cook. 1997. "State accountability for wife-beating: The Indian challenge," The Lancet, 349(Supplement 1): S10-S12.

Khan, Azizur R. and Mahabub Hossain. 1989. The Strategy of Development in Bangladesh. London: Macmillan.

Koenig, Michael A., Saifuddin Ahmed, Mian Bazle Hossain, and A. B. M. Khorshed Alam Mozumder. 2003. "Women's status and domestic violence in rural Bangladesh: Individual-and community-level effects," Demography, 40(2): 269-288.

Lindenbaum, Shirley. 1981. "Implications for women of changing marriage transactions in Bangladesh," Studies in Family Planning, 12(11): 394-401. 
Mannan, M. A. 2002. "Violence against women: Marital violence in rural Bangladesh." CPD-UNFPA Paper No. 20. Dhaka, Bangladesh: Centre for Policy Dialogue.

Rahman, A. 1999. "Micro-credit initiatives for equitable and sustainable development: Who pays?" World Development, 27: 67-82.

Rao, Vijayendra. 1998. "Wife-abuse, its causes and its impact on intra-household resource allocation in rural Karnataka: A 'participatory' econometric analysis," in Gender, Population and Development, eds. M. Krishnaraj et al. Delhi: Oxford University Press.

. 1993a. "Dowry 'inflation' in rural India: A statistical investigation," Population Studies, 47(2): 283-293.

. 1993b. "The rising price of husbands: A hedonic analysis of dowry increases in rural India," Journal of Political Economy, 101(4): 666-677.

Sandanshiv, D. N. and J. Mathew. 1995. "Legal reform in dowry laws," in Kali's Yug: Empowerment, Law and Dowry Death, ed. Rani Jethmalani. New Delhi: HarAnand, pp. 79-93.

Schuler, Sidney R., Syed M. Hashemi, Ann P. Riley, and Shireen Akhter. 1996. "Credit programs, patriarchy and men's violence against women in rural Bangladesh," Social Science \& Medicine, 43(12): 1729-1742.

Sharma, Ursula. 1980. Women, Work, and Property in North-west India. New York: Tavistock Publications.

StataCorp. 2003. Stata Statistical Software: Release 8.0. College Station, TX: Stata Corporation.

Steele, Fiona, Sajeda Amin, and Ruchira T. Naved. 2001. "Savings/credit group formation and change in contraception," Demography, 38(2): 267-282.

Tambiah, Stanley J. 1989. "Bridewealth and dowry revisited: The position of women in Sub-Saharan Africa and North India," Current Anthropology, 30(4): 413-435. . 1973. "Dowry and bridewealth and the property rights of women," in Bridewealth and Dowry, eds. Jack Goody and Stanley J. Tambiah. London: Cambridge University Press.

United Nations Population Fund. 2000. State of World Population 2000. New York: UNFPA. 
Verma, Ravi K. and Martine Collumbien. 2003. "Wife beating and the link with poor sexual health and risk behavior among men in urban slums in India," Journal of Comparative Family Studies, 34 (1): 61-74.

Zhang, Junsen and William Chan. 1999. "Dowry and wife's welfare: A theoretical and empirical analysis," Journal of Political Economy, 4: 786-808. 


\section{POLICY DIVISION WORKING PAPERS}

If still in print, single copies of up to three working papers from 1989 through 2003 are available free of charge.

Beginning with the 2004 issues, the working papers will no longer be available in print format. Instead they will be distributed electronically. As each new paper is completed subscribers will be notified by e-mail and a link to the paper will be provided.

To subscribe to the Policy Research Division working paper e-mail notification list, or to obtain back issues from 1989 to 2003, please send your request to prdwp@popcouncil.org.

PDFs of recent issues are available at www.popcouncil.org/publications/wp/prd/rdwplist.html

2004

195 Luciana Suran, Sajeda Amin, Lopita Huq, and Kobita

Chowdury, "Does dowry improve life for brides? A test of the bequest theory of dowry in rural Bangadesh."

194 Barbara S. Mensch, Monica J. Grant, Mary P. Sebastian, Paul C. Hewett, and Dale Huntington. "The effect of a livelihoods intervention in an urban slum in India: Do vocational counseling and training alter the attitudes and behavior of adolescent girls?"

193 Amanda Ritchie, Cynthia B. Lloyd, and Monica Grant. "Gender differences in time use among adolescents in developing countries: Implications of rising school enrollment rates."

192 John Bongaarts. "Long-range trends in adult mortality: Models and projection methods."
191 John Koku Awoonor-Williams, Ellie S. Feinglass, Rachel Tobey, Maya N. Vaughan-Smith, Frank K. Nyonator, Tanya C. Jones, and James F. Phillips, "Bridging the gap between evidence-based innovation and national healthsector reform in Ghana."

190 Kelly Hallman, "Socioeconomic disadvantage and unsafe sexual behaviors among young women and men in South Africa."

189 Toshiko Kaneda, Zachary Zimmer, and Zhe Tang, "Differentials in life expectancy and active life expectancy by socioeconomic status among older adults in Beijing."

188 Cynthia B. Lloyd and Monica J. Grant, "Growing up in Pakistan: The separate experiences of males and females."

187 Zachary Zimmer, Xianghua Fang, Toshiko Kaneda, Zhe Tang, and Julia Kwong. "Trends and transitions in children's coresidence with older adults in Beijing municipality."

\footnotetext{
* No longer available as a printed publication. Download electronic file from Web site only.
} 
186

Sajeda Amin and Alaka M. Basu.

"Popular perceptions of emerging influences on mortality and longevity in Bangladesh and West Bengal."

185 John Bongaarts. "Population aging and the rising cost of public pensions."

184 Mark R. Montgomery and Paul C. Hewett. "Urban poverty and health in developing countries: Household and neighborhood effects.

2003

183 Agnes R. Quisumbing and Kelly Hallman. "Marriage in transition: Evidence on age, education, and assets from six developing countries."

182 Paul C. Hewett, Barbara S. Mensch, and Annabel S. Erulkar, "Consistency in the reporting of sexual behavior among adolescent girls in Kenya: A comparison of interviewing methods."

181 Zachary Zimmer, Linda G. Martin, and Hui-Sheng Lin, "Determinants of old-age mortality in Taiwan."

180 Frank K. Nyonator, J. Koku Awoonor-Williams, James F. Phillips, Tanya C. Jones, and Robert A. Miller, "The Ghana Community-based Health Planning and Services Initiative: Fostering evidence-based organizational change and development in a resourceconstrained setting."
179 John Bongaarts and Griffith Feeney, "Estimating mean lifetime."

178 Elizabeth F. Jackson, Patricia Akweongo, Evelyn Sakeah, Abraham Hodgson, Rofina Asuru, and James F. Phillips, “Women's denial of having experienced female genital cutting in northern Ghana: Explanatory factors and consequences for analysis of survey data."

177 John Bongaarts, "Completing the fertility transition in the developing world: The role of educational differences and fertility preferences."

176 Cynthia B. Lloyd and Paul C. Hewett, "Primary schooling in sub-Saharan Africa: Recent trends and current challenges."

175 James F. Phillips, Tanya C. Jones, Frank K. Nyonator, and Shruti Ravikumar, "Evidence-based development of health and family planning programs in Bangladesh and Ghana."

174 Geoffrey McNicoll, "Population and development: An introductory view."

173 Paul Demeny, "Population policy: A concise summary."

172 Zachary Zimmer, Napaporn Chayovan, Hui-Sheng Lin, and Josefina Natividad, "How indicators of socioeconomic status relate to physical functioning of older adults in three Asian societies."

\footnotetext{
* No longer available as a printed publication. Download electronic file from Web site only.
} 
171 Sajeda Amin and Nagah H. Al-

Bassusi, "Wage work and

marriage: Perspectives of

Egyptian working women."

170 Ravai Marindo, Steve Pearson, and John B. Casterline, "Condom use and abstinence among unmarried young people in Zimbabwe: Which strategy, whose agenda?"

169 Zachary Zimmer and Julia Dayton, "The living arrangements of older adults in sub-Saharan Africa in a time of HIV/AIDS."

168 Paul C. Hewett, Annabel S. Erulkar, and Barbara S. Mensch, "The feasibility of computerassisted survey interviewing in Africa: Experience from two rural districts in Kenya."

2002

167* Dominic K. Agyeman and John B. Casterline, "Social organization and reproductive behavior in southern Ghana."

159 Carol E. Kaufman, Shelley Clark, Ntsiki Manzini, and Julian May, "How community structures of time and opportunity shape adolescent sexual behavior in South Africa."

158 Geoffrey McNicoll, "Demographic factors in East Asian regional integration."

157 Zachary Zimmer and Sovan Kiry Kim, "Living arrangements and socio-demographic conditions of older adults in Cambodia."

156 John Bongaarts and Griffith Feeney, "How long do we live?"

\footnotetext{
* No longer available as a printed publication. Download electronic file from Web site only.
} 
155 Zachary Zimmer, Linda G. Martin, and Ming-Cheng Chang, "Changes in

functional limitations and survival among the elderly in Taiwan: 1993, 1996, and 1999."

* No longer available as a printed publication. Download electronic file from Web site only. 